\title{
Economics of Livestock Production And Marketing in Nigeria*
}

\author{
$B y$ \\ Prof. S. Olajuwon Olayide** \\ Department of Agric. Economics \\ University of Ibadan, Ibadan.
}

\section{INTRODUCTION}

AN economic analysis of livestock production and marketing is such a wide topic that one can only cover in a most general and perfunctory manner. But in order to confine oneself to the theme of this years conference which is "Towards efficient production of meat in Nigeria," the paper will concentrate largely on what an economist considers those aspects of his own discipline that are relevant in examining economic efficiency in livestock production.

It is therefore appropriate to indicate the typology of livestock of interest since economic efficiency will differ from type to type. In terms of scientific-economic categorisation, interest centres on economic aspects of production for monogastrics (such as pigs) ruminants (such as beef cattle, dairy cattle, sheep, goats) aves (such as poultry, ducks, turkeys, guinea fowls) wildlife (especially the wild herbivores) and fishes (both fresh water and oceanic). Interests in these classes arise largely from their production of protein in terms of animal products for human consumption.

It must be placed on record that protein supply comes from both animal and vegetable sources and what is of economic interest is the efficiency of its production from whatever source and the relative magnitudes of their contributions to human welfare in terms of the digestion, absorption and assimilation of what is ingested. For instance, it has been estimated that daily per capita available proteins to Nigerians in $1968 / 69$ were 26.21 grams from grains, 10.58 grams from starchy roots and tubers, 6.30 grams from pulses, 8.32 grams from livestock products and 2.42 grams from other vegetable sources. Thus 45.51 grams were available from vegetable sources and only 8.32 from livestock sources, making a total of 53.83 grams. (1)

Considering the fact that the endproduct of the input-output systems of livestock industry is the focus of attention, the economics of animal protein production becomes crucial for both producers and consumers. On the producer side, interest centres on productive efficiency with respect to minimum costs, maximum output and optimum distribution. On the consumer side, interest centres on the income structure in terms of purchasing power, the whiplash effects of income on the poor, who pays for the heavy costs of producing animal proteins? And what are the payoffs, especially in terms of health of the manpower resources, adequate nutrition, effects of malnourishment, costs of hospitalisation, and labour productivity? To examine the various issues involved, section two will discuss relevant aspects of livestock econo-

Invited Paper Presented at the Annual Conference of the Nigerian Society For Animal Production, held at the University of Ibadan. Nigeria, March 1976.

*: Dr. S. O. Olayide is Professor and Head of the Department of Agricultural Economics and Dean oft he Faculty of Agriculture and Forestry, University of Ibadan, Nigeria. 
mics whilst section three will concentrate on livestock management economics. Section four will examine the costs and returns structure whilst section five will discuss livestock marketing economics. Section six comprises the conclusion of the paper.

\section{Livestock Production Economics}

The starting point for a meaningful consideration of the economics of livestock production in Nigeria is an examination of the industry's performance. Table $I$ is a presentation of livestock density per thousand people in Nigeria for the year $1970 / 71$. It is seen that the density is very low and this implies considerably low livestock products supplies. The scarcity of products resulting has the end-result of engendering high product prices and thereby ensuring that imported products enjoy competitive advantage of being cheaper apart from better quality. This continuing shortage has been such as to lead to large-scale importation of meat and other products sold to consumers at subsidised prices.

The pogr performance registered in this simplistic approach has been due largely to the essentially traditional free-range and/ or scavengering systems of livestock production in the country. In other words, economics and commercial approaches have had very little contact and/or impact on our livestock industry. (2) To avert the declining performance and the consequent worsening of the animal protein problem, attention has to be focussed on five maior aspects of livestock economics:

\section{(a) Feed Economics}

Of interest here is the efficiency of feed conversion into livestock products. Two basic issues are involved. The first is the magnitude of the feed requirements. This can be obtained from an estimate of the livestock population and the corresponding feed required for efficient production. Table 2 is a presentation of this information. Examining the three planes of nutrition, it is seen that feed requirements run into millions of tonnes for each class of livestock with the possible exception of pigs and broilers. Second is the quality of the feed in terms of its nutrient components required by the various classes of livestock. Feed economics thereby involves the provision of nutritionally adequate requirements of feed magnitudes

TABı... 1

NIGERTA

Livestork Density Per Thousand People 1970/71 (Numbers)

\begin{tabular}{|c|c|c|c|c|c|c|}
\hline State & $\begin{array}{c}\text { Estimated Human } \\
\text { Population }(1970 / \\
71 \text { Million })\end{array}$ & Cattle & Goat & Sheep & Pigs & Poultry \\
\hline $\begin{array}{l}\text { Benue-Plateau } \\
\text { East-Central } \\
\text { Kano } \\
\text { Kwara } \\
\text { Lagos } \\
\text { Mid-Western } \\
\text { North-Central } \\
\text { North-Eastern } \\
\text { North-Western } \\
\text { Rivers } \\
\text { South-Eastern } \\
\text { Western }\end{array}$ & $\begin{array}{r}4.803 \\
8.656 \\
6.917 \\
2.871 \\
1.727 \\
3.038 \\
4.908 \\
9.337 \\
6.868 \\
1.853 \\
4.339 \\
11.364\end{array}$ & $\begin{array}{r}79 \\
12 \\
71 \\
46 \\
2 \\
6 \\
152 \\
428 \\
314 \\
2 \\
3 \\
9\end{array}$ & $\begin{array}{r}93 \\
122 \\
175 \\
70 \\
3 \\
166 \\
407 \\
1,071 \\
1,574 \\
22 \\
69 \\
266\end{array}$ & $\begin{array}{r}72 \\
61 \\
78 \\
62 \\
3 \dot{35} \\
183 \\
535 \\
1259 \\
22 \\
23 \\
370\end{array}$ & $\begin{array}{r}11 \\
3 \\
1 \\
7 \\
3 \\
13 \\
8 \\
3 \\
- \\
3 \\
4 \\
23\end{array}$ & $\begin{array}{r}2,247 \\
1,550 \\
1,614 \\
859 \\
285 \\
789 \\
1,606 \\
1,227 \\
1,155 \\
1,482 \\
724 \\
1,078\end{array}$ \\
\hline Nigeria (Total) & 66.682 & 122 & 444 & 308 & 8 & 1,292 \\
\hline
\end{tabular}

Source: Calculations are based on figures supplied by the NLDC and FOS. (Personal Communications) $+=$ less than 1.0 . 
TABLE 2

NIGERIA

Livestock Feed Requirements

\begin{tabular}{|c|c|c|c|c|c|}
\hline \multirow[b]{2}{*}{ Livestock } & \multirow{2}{*}{$\begin{array}{l}\text { Estimated Live- } \\
\text { stock Popula- } \\
\text { tion for } 1975 \\
\text { (million) }\end{array}$} & $\begin{array}{l}\text { Estimated Bree } \\
\text { ing Stock P?- } \\
\text { quired for } 1976\end{array}$ & \multicolumn{3}{|c|}{$\begin{array}{l}\text { National Feed Requirements } \\
\text { (in million tonnes) }\end{array}$} \\
\hline & & 4.870 & 1.357 & 1.696 & 2.022 \\
\hline Pigs & 0.989 & 1.200 & 0.350 & 0.438 & 0.580 \\
\hline Poultry (layers) & 23.827 & 4.000 & 1.532 & 1.670 & 1.809 \\
\hline Broilers & 71.481 & 60.000 & 0.528 & 0.660 & 0.926 \\
\hline
\end{tabular}

Source: S. O. Olayide, "Agricultural Policy for Nigerian Small Farmers," in Nigeria Small Farmers: Problems and Prospects (Eds.) S. O. Olayide and S. K. T. Willians (In Press).

at the least cost possible.(3) Considering the fact that mixed feeds can be compounded from well over 500 feeding stuffs each containing different levels of TDN (Total digestible nutrient), TDM (Total Dry Matter), DP (digestible Protein), fat, fibre, NFE (Nitrogen free extract) and minerals (such as calcium, phosphorus, potassium) and at varying costs per unit, various methods have been used to compound livestock rations. The least cost feeds jssue has been effectively tackled through the use of linear programming tool backed by continuing research testing of what has been compounded. Here is an area of feed economics which has been given very little attention by livestock scientists and livestock economist in this country.

\section{(b) Breeding Stock Economics}

The issue of optimal replacement of annual off-take and number lost through various forms of death can be seriously tackled through breeding programmes. Estimated breeding stock for various classes of livestock is presented in column two of table 2. Livestock breeding is a very expensive and long-term programme that cannot be undertaken by individual producers. Involved are (i) issues of selection in terms of natural, artificial and systems of selection, (ii) principles of breeding with respect to inbreeding, linebreeding, outbreeding and crossbreeding, and (iii) systems of breeding with respect to traits of economic importance, heritability factor, selection indices, genetic correiations and when to use each form of breeding. $\left(^{5}\right)$ The time, expense, research and breeding personnel and logistics support required can only be borne through corporations and institutes by government, since the social benefits of such a programme exceed the social costs.

\section{(c) Inputs Economics}

Involved here is the economics of other essentjal inputs such as housing and space, water and feeding equipments, labour and livestock medicants. Exemplifying with broiler production, it must be stressed that these other inputs are very important and crucial to increased productivity. Successful broiler growing involves a continuous factory-line production on a fixed floor space of not less $0.116 \mathrm{sq}$. metre per bird at any stage of the birds growth. The greater the number of batches turned out per production cycle the higher will be the productivity. Hence several well-constructed deep-litter pens house to house the various batches for a time-phased production constitute an important input. The same is true of the provision of adequate watering facilities, feeding troughs, feed depot and moving-weighingpackaging equipments which should constitute essential parts of the fixed assets properties for successful broiler growing. An equally important input is labour requirements for a given number of birds so that the duty of each broiler attendant is more or less fixed and completely routinised. This ensures efficien supervision of properly trained labour to 
reduce costs. Livestock medicants are important inputs in broiler production. Their timely application ensures minimal death and increased producitivity. $\left({ }^{6}\right)$

\section{(d) Output-Byproduct Economics}

The production function, which is a technical specification of the relationship between input and output of a given product, is the logical foundation of output economics. Exemplifying from dairy, the output of milk (M) is a function of the input of concentrates $(C)$ and hay $(H)$ given other cooperating factors (Xi). This is mathematically rendered as:

EQ. 1. $M=f\left(C, H_{i} X_{i}\right)$; for $i-1, \ldots n$. Feeding inolves the combination of concentrate and hay to serve two functions. First is the maintenance of basic metabolism and second is the output of milk. The economics involved centres around the fact that a dairy animal can be fed to the point of maximum output but that maximum happens not to be the economically optimum output level. This distinction can be rendered mathematically from an explicit production function:

EQ.2. $\mathbf{M}=\mathrm{bo}_{0}+\mathrm{b}_{1} \mathrm{C}+\mathrm{b}_{2} \mathrm{C}^{2}+\mathrm{b}_{3} \mathrm{H}+$ $b_{4} \mathrm{H}^{2}+b_{5} \mathrm{CH}$.

If we take the partials of this function, set them equal to zero, solve and arrange the results in matrix form we have:
EQ.3.
(C) $\quad\left(-2 b_{2}-b_{5}\right)^{-1}$
$\left(b_{1}\right)$
(H) $\left(-b_{5}-2 b_{4}\right) \quad\left(b_{3}\right)$

The solution to this gives the physical maximum milk output. The economic maximum output is obtained by taking the partials of the same function, setting them equal to the inverse price ratios instead of to zero, where $r_{1}$ is the per unit price of concentrate, $r_{2}$ is the per unit price of hay and $p$ is the per unit price of milk and solving the result obtained in matrix form is as follows:

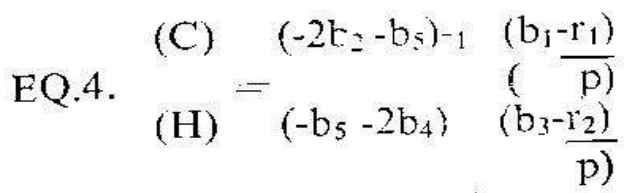

A solution of this gives the economic output level which is lower than the physical maximum because:
EQ.5. ${ }_{\left(b_{3}\right)}^{\left(b_{1}\right)}>\frac{\left(b_{1}-\frac{\left.r_{1}\right)}{p}\right)}{\left(b_{3}-\frac{\left.r_{2}\right)}{p}\right.}$

These are the relations of relevance to livestock output economics. Other relations of interest include the (i) marginal physical product (MPP) of inputs, (ii) rates of technical substitution (RTS) of one input for another, and (iii) elasticities of production (E) with respect to each of the inputs.(7)

The second aspect is that of by-products from a given output. From a given dairy herd total output may be rendered as follows:

EQ.6. $Q=\sum_{i=\cdots 1}^{n} q_{i}$; for $i \ldots 1,2, \ldots, n$. where the various products include milk, meat from culled animals, cheese, butter, hide, blood, bone, animal dung, etc. The extent of the production and the utilisation of these by-products will be determined largely by the scale and level of integration of the given enterprise.

Third is the economics of grade and quality. More income is earned per unit by getting high grade and high quality output probably at slight increases in cost per unit. The profitability of high quality and high grade produce, given differential pricing, cannot be in doubt. But quite unfortunately, many livestock products are not graded with the possible exception of eggs. The quality factor is yet to be given any meaningful attention. Consequently, substantial losses due to qualitative and grade factors are expericnced annually and these aggravate the animal protein problem. There is therefore the need to take account of three types of quality differences. First is vertical quality differences in which differing costs of production are involved as between quality levels, since for instance, it costs more to produce eggs of higher quality which requires more careful handling, refrigeration equipment, etc. Second is horizontal quality differences involving no differences in costs of production but there are personal or subjective differences as in preferences of consumers in terms o brown and white eggs. Third is innova- 
tional quality differences in which considered improvements led to a replacement of old products as in the case of eggs containing blood spots being now completely rejected from marketing channel.(8)

\section{(e) Animal Health Economics}

This aspect deals with the minimisation and or elimination of losses due to diseases in animals of economic importance. For example, it is known that about $20 \%$ of all hides and skins already tanned for export are not saleable due to contaminations arising from skin diseases of the domesticated animals that formed the source of this by-product. In value terms, this loss amounted to 1.354 million in 1972 and $\$ 2.498$ million in 1973 and must be about N3.000 million by 1975 . It is known that losses from diseases among animals of economic importance amount to about $10 \%$ of the total value of the animals in U.S.A. Under Nigerian condilions, such losses will approach 25 to $30 \%$ of the total value of the animals.

These losses include those resulting from death of animals, lessened productivity in terms of milk, meat, offspring, other products, working ability (horses and donkeys), and loss of animal byproducts. In addition, there is the loss of human life and lessened productivity resulting from diseases transmitted by animals. Table 3 is a presentation of some common diseases of domesticated animals which largely account for the losses. It is seen from the table that many of them are subject to very high mortality and many have no specific treatment, thereby compounding the magnitude of the losses.

TABI.E 3

Some Common Diseases of Domesticated Animals

\begin{tabular}{|c|c|c|c|c|}
\hline & Diserse & Animal & \multicolumn{2}{|r|}{ Treatment \& Control } \\
\hline $\begin{array}{l}\text { A. } \\
1 .\end{array}$ & $\begin{array}{l}\text { Diseases caused by } \\
\quad \text { Virus } \\
\text { Encephalomyelitis } \\
\text { (several types) }\end{array}$ & $\begin{array}{l}\text { duck, goat, } \\
\text { swine }\end{array}$ & $\begin{array}{l}\text { Transmitted by insects, } \\
\text { causes mental abcration } \\
\text { paralysis and dumbness. } \\
\text { High mortality }\end{array}$ & $\begin{array}{l}\text { Vaccination, protection } \\
\text { from exposure to insects, } \\
\text { quarantine of sick stock; } \\
\text { no specific treatment. }\end{array}$ \\
\hline 2. & $\begin{array}{l}\text { Foot-and-mouth } \\
\text { disease. Vesicular } \\
\text { stomatitis Vesicular } \\
\text { exanthema }\end{array}$ & $\begin{array}{l}\text { cow and other } \\
\text { ruminants. } \\
\text { cow and horse } \\
\text { swine }\end{array}$ & $\begin{array}{l}\text { contagious, causes fever } \\
\text { and vesicles on feet and } \\
\text { mouth; low mortality but } \\
\text { higit morbidity (debility with } \\
\text { loss of productivity) }\end{array}$ & $\begin{array}{l}\text { No treatment; eradica- } \\
\text { tion by slaughter of } \\
\text { diseased anima. }\end{array}$ \\
\hline & Hog cholera & Swine & $\begin{array}{l}\text { Spread by contact, flies, } \\
\text { garbage: causes fever } \\
\text { prostration, hemorrhages, } \\
\text { high mortality }\end{array}$ & $\begin{array}{l}\text { Vaccination with anti- } \\
\text { serum and virus before } \\
\text { exposure to disease; } \\
\text { administration of anti- } \\
\text { serum after exposure. }\end{array}$ \\
\hline & Mucosal disease & Cow & $\begin{array}{l}\text { spread by contact, causes } \\
\text { erosion lining of digestive } \\
\text { tract; "new" discase; mild } \\
\text { to severe. }\end{array}$ & $\begin{array}{l}\text { No specific treatment; } \\
\text { isolation of affected } \\
\text { animals. }\end{array}$ \\
\hline 5. & Newcastle disease & Fowl & $\begin{array}{l}\text { spread by contact; causes } \\
\text { nervous and respiratory } \\
\text { symptoms; higl mortality. }\end{array}$ & $\begin{array}{l}\text { Vaccination; no specific } \\
\text { treatment. }\end{array}$ \\
\hline 6. & Pox (several types) & $\begin{array}{l}\text { cow, fowl, } \\
\text { goat, horse } \\
\text { sheep, and }\end{array}$ & $\begin{array}{l}\text { spread by contact; causes } \\
\text { fever and skin pustules; } \\
\text { usually mild. }\end{array}$ & $\begin{array}{l}\text { Vaccination; quarantine } \\
\text { of sick animals; no } \\
\text { specific treatment. }\end{array}$ \\
\hline & $\begin{array}{l}\quad \text { Diseases caused by } \\
\text { bacteria } \\
\text { Anthrax }\end{array}$ & $\begin{array}{l}\text { most } \\
\text { namnals }\end{array}$ & $\begin{array}{l}\text { through contaminated soif } \\
\text { and by insects; causes acute } \\
\text { fever and splcen enlarge- } \\
\text { ment; bigh mortality }\end{array}$ & $\begin{array}{l}\text { Vaccination; penicillin } \\
\text { and other antibiotics, } \\
\text { anti-anthrax serum or } \\
\text { combinations of treatment }\end{array}$ \\
\hline
\end{tabular}




\begin{tabular}{|c|c|c|c|c|}
\hline & Disease & Aninal & Characteristics & Treatment \& Control \\
\hline & Blackleg & Ww and shoes? & $\begin{array}{l}\text { through contaminated soil; } \\
\text { causes fever and gas forma- } \\
\text { tion under skin, muscles; } \\
\text { high mortality }\end{array}$ & $\begin{array}{l}\text { Vaccination; pron } \\
\text { cradication of diseased } \\
\text { animals; no specific } \\
\text { treatment. }\end{array}$ \\
\hline 9. & $\begin{array}{l}\text { Brucellosis (Infectious } \\
\text { abortion) }\end{array}$ & $\begin{array}{l}\text { cow, sheep, } \\
\text { fowl, gaat, } \\
\text { horse and } \\
\text { swine }\end{array}$ & $\begin{array}{l}\text { through contact or milk; } \\
\text { causes fever and abortion, } \\
\text { low mortality. }\end{array}$ & $\begin{array}{l}\text { Vaccination; eradication } \\
\text { of diseased animals; no } \\
\text { specific treatment. }\end{array}$ \\
\hline 10. & Leptospirosis & $\begin{array}{l}\text { most } \\
\text { mammals }\end{array}$ & $\begin{array}{l}\text { spread by urine of infected } \\
\text { animals; calises kidney and } \\
\text { liver infection; moderate } \\
\text { to high mortality }\end{array}$ & $\begin{array}{l}\text { antibiotics; isolation of } \\
\text { diseased animals; treat- } \\
\text { ment of carriers; vacci- } \\
\text { nation of susceptible } \\
\text { animals. }\end{array}$ \\
\hline 11. & Mastitis & $\begin{array}{l}\text { cow and other } \\
\text { lactating } \\
\text { animals }\end{array}$ & $\begin{array}{l}\text { under infection spread by } \\
\text { hand or machine milking; } \\
\text { causes inflamation or under } \\
\text { and loss of milk; acute or } \\
\text { chronic; low mortality }\end{array}$ & $\begin{array}{l}\text { antibiotics; control by } \\
\text { proper sanitation and } \\
\text { milking methods. }\end{array}$ \\
\hline & $\begin{array}{l}\text { Shipping fever (hae- } \\
\text { morrhagic septicemia) }\end{array}$ & cow and sheep & $\begin{array}{l}\text { predisposed to stress, } \\
\text { causcs fever and pneumonia } \\
\text { high mortality. }\end{array}$ & $\begin{array}{l}\text { vaccination and tran- } \\
\text { quilizers for prevention; } \\
\text { Sulfonamides and anti- } \\
\text { biotics for treatment. }\end{array}$ \\
\hline 13. & Tetanus (lackjaw) & $\begin{array}{l}\text { horse and } \\
\text { other } \\
\text { nammals }\end{array}$ & $\begin{array}{l}\text { through wound infection } \\
\text { (not contigious) causes } \\
\text { muscle contraction; high } \\
\text { mortality. }\end{array}$ & $\begin{array}{l}\text { tetanus antitoxin for } \\
\text { treatment; tetanus } \\
\text { toxoid for prevention. }\end{array}$ \\
\hline & $\begin{array}{l}\text { Tuberculosis (several } \\
\text { types) }\end{array}$ & mostmammals & $\begin{array}{l}\text { through contaminated feed, } \\
\text { water, milk, and soil,; causes } \\
\text { tubercles and nodules in } \\
\text { longs and other organs; } \\
\text { chronic, progressively fatal. }\end{array}$ & $\begin{array}{l}\text { control by cradication } \\
\text { of diseased animal } \\
\text { no treatment. }\end{array}$ \\
\hline
\end{tabular}

C. Diseases caused by disorders of metabolism.

15. Acetonemia Cow and sheep

fanlty carbohydrate motabolism with high blood gluccse injections for ketones; high mortality. treatment.

16. Mik fever

17. Vitarnin and Mineral

cow and other lactating animals results from sudden drop of blood calciun; causes para. lysis and coma; high mortality. calcium injections for reatment. all species

common in animals kept on mineral deficient soils fed on poor quality feeds. supplemented diet.

Sources: (1) Blood, D.C. \& J. A. Henderson, Veterinary Medicine, Balliere, Tindall \& Cassell, London, 1968.

(2) Cockrili, W.R. (Ed.) The Husbandry and Health of the Domestic Buffalo, FAO, Rome, 1974, pp. $195-275$ 
Probably the greatest source of loss is from the complex of physiolegical and pathological conditions known as infertility and sterility $\left({ }^{9}\right)$ which may account for about $10 \%$ or more of the total. Taken as a group, the parasitic diseases of animals cause losess equal to or greater than the infertility complex. The ectoparasites and the endoparasites are becoming more prolific in attack and destructive of livestock products. Virus and bacterial diseases are increasingly lethal and their incidence has become problematic. Those listed in the table are a few of the several hundreds that affect livestock. (10 'II) Other non-infectious diseases include different kinds of tumors, heart diseases, digestive disorders, poisoning from toxic materials, exostoses or bone enlargements etc. Of these, poisoning of various forms, is increasing in incidence due to drugs, pesticides, toxic plants, mycotoxins, etc. $\left({ }^{12}\right)$

Our economics of heatlh management has, therefore, to be oriented to four fronts with varying costs and benefits. First is prevention through quarantine, immunisation, and animal hygiene. Second is treatment through the use of drugs and other prophylatics. Third is control through all forms of eradication which appcar the most serious in terms of losses. Fourth is through Veterinary Public Health in terms of immunisation schemes, food and meat inspection, and alimentarydrug laws. The economics of animal health has been concentrated up to now on the treatment side. If other cost aspects are not taken account of, annual losses will be subject to a steep upward trend, since a vicious cycle is involved in concentrating only on curative aspect.

\section{Livestock Management Economics}

This is an aspect of the commercialisation of livestock enterprises which is almost non-existing in traditional systems of livestock production. There are three basic issues involved. First is the issue of business management. This involves the use of records specifically to (i) measure financial progress, (ii) serve as a means for economic and tax reporting, and (iii) aid in securing increased profits. Financial progress is measured by the use of the balance sheet and the income statement. Other relevant livestock records for effective business management include those for inventory, feed, crop market, and credit. The profitability of a carefully managed livestock enterprise is measured by comparing outputs with inputs. Efficiency indices are then computed on yearly basis and break-even prices computed for planning and enterprise management purposes. Such information constantly remind the producer the production levels he must attain or the price he must receive to break-even on costs. The time spent on weekly and annual record keeping and analysis which may amount to a total of 30 man-days per year must be regarded as one of the most valuable management variables in economically efficient livestock production in this country. It is one of the preconditions for modernisation and commercialisation of our essentially traditional livestock economy $\left({ }^{13}\right)$

Second is the issue of the economic characteristics of livestock enterprises. Involved in this management issue are (i) the effects of size on costs, production, and returns, (ii) size measure and concepts, (iii) factors affecting size of enterprise, (iv) intensity characteristics, ( $v$ ) diversification, specialisation and enterprise combination dimensions, (vi) flexibility, (vii) multiple utilisation of resources, and (viii) vertical integration factors. For example, the size of labour largely determines beef cattle ranch sizes which are measured in terms of physical quantities of total animals or breeding units and animal units. Sizes are also measured in economic quantities of investment, labour requirement, value of sales, net kilogram of beef produced, inputs and net returns. Animal units are considered the most accurate physical measure to show ranch size, while combination of the economic measures of value of sales and net returns are often used by non-agricltural business. The size factor assumes prominence in view of the determination of economic lot size for small, medium, and large-scale producers or ranchers. Equally important 
is the intensity variable which is defined as the number of inputs used per hectare of land. In this way, ranches may be classified as "extensive operations" since they are limited to a few inputs per hectare or "intensive operations" which make use of large inputs per hectare. The size, intensity, and other six management characteristics are very vital to increased productivity of livestock enterprises in Nigeria. $\left({ }^{14}\right)$

Third is the issue of economics of livestock research. Here, special emphasis should be placed on research in breeding programmes, nutrition and feeding programmes, improved pasture and range management programmes, cattle fattening and feedlot programmes, modernised dairy, piggery, and poultry programmes, and research on reproduction. Generally, livestock research is a costly enterprise beyond the financial resources of producers apart from the fact that very little attention has been given to the economic im plications of research results to make the m operationally useful.(15) This issue has to be tackled very seriously by the government since the social benefits outweigh all social costs.

\section{Cost-Returns Economics}

The structure of costs and returns is perhaps the most significant economic aspects of livestock production. Net income is a function of total output, product price received by producers, total inputs and input price paid by producers. Changes in livestock incomes therefore result from one or more of these four variables. Changes in quantities of either inputs or outputs can be measured by the formula:

EQ.7. $\Delta Q=\sum_{i=1}^{n}\left(Q P_{i}\right)-i=1\left(Q_{0} P_{i}\right)$

where $\Delta \mathrm{Q}$ is the change in quantity or quantity effect, $Q_{i}$ is each of the quantities (produced or used, depending on whether inputs or outputs are being measured), $\mathbf{P}_{i}$ is each of the prices for the appropriate quantities and $Q_{0}$ is each of the quantities of the base year. Similarly price changes can be measured using the formula:

EQ.8. $\left.\left.\Delta \mathrm{P}=\mathrm{i}=1 \mathrm{Q}_{\mathrm{i}} \mathrm{P}_{\mathrm{i}}\right)-\sum_{\mathrm{i}=1}^{\mathrm{n}} \mathrm{Q}_{\mathrm{i}} \mathrm{P}_{0}\right)$

where $\Delta \mathrm{P}$ is the change in price or price effect and $P_{o}$ is each of the base year's prices for the appropriate quantities whilst other variables are as previously defined. These calculation are vital for major economic decisions especially in choice of enterprise factors affecting enterprise costs (Such as, costs of feed, breeding stock, machinery, buildings and improvements, labour, taxes and other miscellaneous inputs), range conditions, and factors affecting enterprise income (such as calf crop, death losses, supplemental feeding, size of business, diversity of enterprises, by-products and marketing prices). The separation of production and price effects is a necessary exercise for a meaningful explanation of changes in income and hence enterprise fortunes from one period or year to another. $\left({ }^{16}\right)$ The total profit function is a planning tool and is of the form:

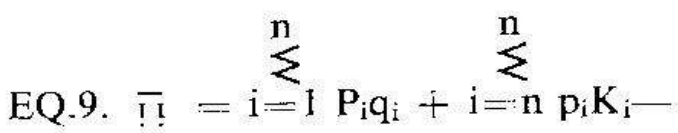

$$
\begin{aligned}
& \sum_{-i=1 r_{i} X_{i}-b \pm i=-1}^{n} P_{i} S_{i}
\end{aligned}
$$

where $\bar{T}$ is total profit, $P_{j}$ is per unit product price, $q_{i}$ is the product, $K_{i}$ is the byproduct, $r_{i}$ is the per unit input price, $X^{-}$ is the input, $b$ is the fixed cost and $S i$ is product subsidy or taxation/duty. The fact that our livestock economy is essentially of the traditional free range system means that producers are not costs-returns conscious. This situation has to be reversed in our efforts to solve the animal protein problem through the modernisation and commercialisation of our livestock industry. Profit maximisation achieved either through cost minimisation, or output maximisation or a combination of both constitutes the frame within which costsreturns economics of livestock production should realistically operate. 


\section{Livestock Marketing Economics}

This fourth aspect of the economics of livestock production and marketing is significant for a number of reasons. First is the issue of product utility in which the consumer is interested. Second is the role of marketing functions in adjusting demand and supply and thus determining product price. Third is the issue of the efficiency and/or effectiveness of marketing institutions and typology of market places. Fourth is the magnitude and/or effects of marketing problems on overall efficiency of the livestock industry.

In strict economic parlance, consumers seek to maximise utility through rational selection from the alternatives available to them subject to given budget constraint. This raises the issue of income, prices of given commodity, substitutes and complements as the main variables affecting the size and composition of the consumers food basket. Related to these variables, account is frequently taken of market functions which are of three main forms. The first is "concentration" which involves the collection of goods produced in small lots into larger quantities at central points in order to market them more efficiently. It is important in commodities sold in their natural state as in eggs. The second is "equalisation" which consists of adjustments of supply to demand on the basis of time, quantity, quality and form. The third is "dispersion" which involves the process of dispersing towards the ultimate consumers or users the commodities which have been concentrated and/or equalised at central points. These three market functions are cost items to the consumer and the efficiency of their performance significantly affects product prices paid by consumers. $\left({ }^{17}\right)$

Marketing institution may be thought of in terms of individual sellers, wholesalers, retail institutions, cooperatives and state trading institutions which in addition to buying and selling are inolved in market finance, marketing risk, seeking market information and conforming to market standards all with the objective of maximising profit, which again is a cost item to the ultimate consumers.
Markeling problems centre around bottlenecks in the performance of marketing functions, organisation of marketıng inst1tutions, structure of the commoditues inolved, preferences of the consumers and government policies with respect to taxation and subsidisation among otners. In developing countries such as Nigeria, there are additional problems created by the structure of the market place, spatial factors, transportation, unit of sale and level of education of buyers and selters. (18) Involved in livestock marketing economics is the central issue of marketing efficiency around which other aspects revolve. The chief concern is product price which is adversely affected by market imperfections and inefficiencies of varying forms. High prices for livestock products restrict such nutritionally essential commodities to the high income consumers. It is the extent to which market imperfections, inefficiency and "sticky" market margins influence product prices that government intervention in pricing livestock products comes in. The objectives of such interventions are (i) to reduce price and income instability, (ii) to improve the allocation of resources, (iii) to increase self-sufficiency in food and fibre, and (iv) to raise the average level of prices and incomes. Methods of government intervention of interest to livestock products prices include, tariffs, subsidies, government bulk purchases (as in recent chilled meat importation), and deficiency payments. $\left({ }^{19}\right)$

\section{Conclusion}

The Nigerian livestock industry is largely characterised by traditional transhumance and traditional free-range and scavengering systems of production. This structure is operated by a large number of small producers with very little capital. $\left({ }^{20}\right)$ This structure needs to be completely changed to progressively evolve fully commercialised systems of production. In such restructuring, considerable use of economics is called for in terms of feed, stock, essential inputs, output-byproducts, animaI health, business management, costs-returns management and marketing. In such an all-out effort, economists, veterinarians 
and livestock scientists have to graple with applied multi-disciplinary research into the various aspects of the economics of livestock production and marketing. The objectives of such an all-out research endeavour should include the minimisation-elimination of animal protein problem, the enhancement of the well-being of the nation's manpower resources, the attainment of maximum output and optimai trade in livestock business, the minimisation of all cost items in production and marketing, the optimal supply of essential livestock inputs and the enhancement of producer incomes. These objectives can be summarised in terms of feed, production, byproducts, stock, feed conversion and nutritional efficiencies in livestock business. With these as goals to which we as scientists are fully committed and which governments are fully prepared to support, the rapid commercialisation of Nigeria's livestock industry cannot be in doubt.

\section{REFERENCES}

Olayide, S.O., et. al. 1972. A Quantitative Analysis of Food Requirements, Supplies And Demands In Nigeria, 1968-1985. Ibadan University Press, Ibadan, Nigeria. 113pp.

OLAyide, S.O. 1975. "Agriculture In The Federal Republic of Nigeria: A Review of Developments Up to 1975," Invited Paper, Nigeria Institute of International Affairs, Lagos, Nigeria.

Olayide, S.O. 1972. Economic Efficiency In Dairy And Beef Cattle Feeding (Unpublished) $P h . D$. Dissertation University of California, Davis U.S.A.

Morrison, F.B. 1956. Feeds And Feeding, The Morrison Publishing Coy., Clinton, Iowa, U.S.A.

Lasley, John F. 1963. Genetics of Livestock Improvement, Prentice-Hall Inc. Englewood Cliffs, N.J. U.S.A., 342pp.

Olayide, S.O. 1972. Commercial Broiler Growing: Structure of Costs And Returns, Tcchnical Report AER No. 72. 1, $108 \mathrm{pp}$.
Or.AYIDE, S.O., and EARl. O. HEADY. Introduction To Agricultural Production Economics, University Press, Ibadan, Nigeria (In Precs).

Aвbor, L. 1955. Quality And Competition, Columbia University Press, New York, Chapter 10 .

Arthus, G.H. 1974. Veterinary Peproduction and Obstetrics Baillierc, Tindall and Cassell, London, 1974.

COckrili, W.R. Ed. 1974. The Hushandry And Health of the Donestic Buffalo, FAO, Rome, pp. 195-275.

Blood, D.C. and Henlerson, J. A. 1974. Veterinary Medicine, Baillicre, Tindall and Cassell, London.

Clarke, E.G.C., and Clarke, M. L. 1975. Veterinary Toxicology, Bailliere, Tinda London.

Olayide, S.O. 1969. Farm Records And Accounts. As Tools In Efficient Farm Management, (Mimeo) Paper presented at the In-service Training Course For Agric. Extension Officers, Western Nigeria M.A.N.R., Ibadan Nigeria. 25 pp.

Gray, James A. 1968. Ranch Economics, Iowa State University Press, Ames, Iowa U.S.A., pp. $106-156$.

Olayide, S.O. 1973. "Some Aspects of Beef Production In Nigeria," in Factors Of Agricultural Growth In West Africa (Ed.) I.M. Ofori, ISSER Legon, Ghana, pp. 240-250.

Goodsell, W.D., and GRAY, J. R. 1961, Cattle Ranches, Organisation, Costs and Returns, Agric. Econ. Report No. 1, ERS, USDA, Washington D.C., U.S.A.

Tousley, F..D., Clark, E. and Clark, F. E. 1960 Principles of Marketing. The Macmillan Coy., New York, 3-22. (716 pp.)

Olayide, S.O. 1969. "Economics of Inter-State Marketing of Farm Products: A Spatial Analysis of Transportation Costs," Bulletin of Rural Economics \& Sociology Vol. 4, No.2, pp. $155-182$.

Tomer, W.G., and Robinson, K. L. 1972 Agricultural Product Prices, Cornell University Press, Ithaca, New York, pp. 277-303 (376 pp.)

Olayide, S.O., and Williams, S. K. T, (Eds.) 1976. Nigerian Small Farmers: Problems And Prospects, (in Press) 